\title{
Reflective Practices To Explore Postgraduate Students Learning Experience In Mobile Learning Platform
}

\author{
Malini Thiagraj*, Abdul Malek Abdul Karim \\ College of Arts and Sciences, School of Education and Modern Languages, University Utara Malaysia (UUM) Sintok, Kedah, Malaysia \\ *Corresponding author: malini_thiagraj@ahsgs.uum.edu.my
}

Article history: Received:13 February 2020 Received in revised form: 13 May 2020 Accepted: 13 May 2020 Published online: 31 August 2020

\begin{abstract}
Mobile Learning (M-learning) has great potential to be an effective learning tool in creating meaningful learning experiences. The purpose of this study is to explore postgraduate students M-learning experiences in Massive Open Online Courses (MOOCs) platform. Reflective practice is used to measure the students M-learning experience based on mobile-based task-centered activity. This study is qualitative in nature employed thematic analysis method. Therefore, 34 postgraduate students from a public university in Malaysia were selected for this purposive sampling. The postgraduate students were initially introduced to M-learning course content in FutureLearn platform followed by reflective practices. Pre-reflective practice happened before students are enlisted into the M-learning process, During-reflective process in FutureLearn platform and Post-reflective upon completion of task-centered activity. The findings revealed that majority of these students were unsure of M-learning platform during the pre-reflective stage. This is due to lack of prior knowledge and experience in M-learning platform using mobile devices as real time hindered the students from exploring. However, most of them progress to gained positive M-learning experiences as their able to monitoring and self-evaluate their own learning development throughout this learning process and completed the task-centered activity successfully. Therefore, the reflective approach practice has given students insight on their meaningful learning experience and their own learning capabilities.
\end{abstract}

Keywords: Mobile learning experience, Future Learn (MOOCs) platform, Reflective practice, Task centered activity.

\begin{abstract}
Abstrak
Mobile Learning (M-learning) mempunyai potensi besar untuk menjadi alat pembelajaran yang berkesan dalam mencipta pengalaman pembelajaran yang bermakna. Tujuan kajian ini adalah untuk mengenalpasti pengalaman pelajar M-learning pascasiswazah dalam platform Massive Open Online Courses (MOOCs). Amalan reflektif digunakan untuk mengukur pengalaman pelajar dalam M-learning berdasarkan aktiviti berpusatkan tugas. Kajian ini bersifat kualitatif yang digunakan kaedah analisis tematik. Oleh itu, 34 orang pelajar lepasan ijazah dari sebuah universiti awam di Malaysia telah dipilih untuk persampelan purposive ini. Pelajar pasca siswazah pada mulanya diperkenalkan kepada kandungan kursus M-learning dalam platform FutureLearn diikuti dengan amalan reflektif. Amalan pra-reflektif berlaku sebelum pelajar disenaraikan dalam proses pembelajaran M-Learning, Proses reflektif semasa dalam platform FutureLearn dan Post-reflektif setelah selesai aktiviti berpusatkan tugas. Hasil kajian ini mendedahkan bahawa majoriti pelajar- ini tidak pasti pada platform M-learning semasa peringkat pra-reflektif. Ini disebabkan kurangnya pendedahan dan pengalaman pembelajaran terdahulu dalam platform Mlearning menggunakan peranti mudah alih sebagai masa nyata menghalang pelajar dari meneroka. Walau bagaimanapun, kebanyakan mereka maju untuk memperoleh pengalaman M-pembelajaran positif kerana mereka dapat mengawasi dan menilai sendiri perkembangan pembelajaran mereka sepanjang proses pembelajaran ini dan menyelesaikan aktiviti berpusatkan tugas dengan jayanya. Oleh itu, amalan pendekatan reflektif memberi pemahaman pelajar tentang pengalaman pembelajaran yang bermakna dan keupayaan pembelajaran mereka sendiri.
\end{abstract}

Kata kunci: Pengalaman Mobile Learning, FutureLearn (MOOCs) platform, Amalan reflektif, Aktiviti berpusatkan tugas.

(C) 2020 Penerbit UTM Press. All rights reserved

\subsection{INTRODUCTION}

At present, students learning has tremendously changed after the arrival of mobile learning (M-learning). Undeniably, previous traditional educational learning has now been transformed into digital learning where learners have immediate access to a vast array of information. In simple words, M-learning can be defined as the use of mobile devices for learning purposes (Alsadoon, 2018). M-learning has a great potential to be an effective learning tool in creating meaningful learning experiences and thus, be independent of time and place (Sonmez, Gocmez, Uygun \& Ataizi, 2018). Apparently, the learning experiences are unique and personal to every learner (Law \& Sun, 2012). Therefore, M-learning providing the opportunity to change the existing learning strategies to give students a much flexible approach to managing their learning experiences (Al-Hunaiyyan, Alhajri, \& Al-Sharhan, 2018).

Meaningful learning experience appears to be essential in understanding how experience can become a learning experience. This is not about observation, a passive undergoing of something, but involve a learner an active engagement with the environment. Therefore, a well-designed mobile application able to provide students with direction over learning, as they control their learning and practice in their 
own time, pace (Poore, 2016), and create a meaningful learning experience. They also have immediate access to any information. Yet, this immediate access is changing the way learners think about work. The M-learning platform has its' pros and cons. Meaningful learning experience enables the students to diagnose and analyse its' advantages with an abundance of information at their fingertips and the disadvantages of not falling aside in mobile distraction. Therefore, reflection is an essential practice for students to encourage thinking about one's own learning experience. The reflective practice supported transformative and deep learning which is making sense of and learning from, their experiences (Harvey, Walkerden, Semple, Mclachlan, \& Lloyd, 2019).

However, there has been little discussion on the postgraduate students reflective practice in the use of M-learning experience in Mlearning platform (Anderson \& Herr, 1999; Johnson, et al. 2013; Marinagi, Skourlas \& Belsis, 2013) as many of them still lack prior Mlearning knowledge and experience (Grant \& Barbour, 2013; Sánchez-Prieto, Olmos-Migueláñez, \& García-Peñalvo, 2016). Therefore, the purpose of this study is to explore the postgraduate students M-learning experiences using reflective practice on task-centered activity based on FutureLearn (MOOCs) platform. Thus, reflective practice (pre-, during- and post-reflective) has taken place during the students M-learning process. The rationale behind employing this reflective practice is based on Schon's (1983) ideas in his writing "The reflective practitioner". Schon identified these reflective practices as a vital element as the students could be aware of ones' implicit knowledge and comprehend the experience of learning.

\subsection{LITERATURE REVIEW}

\subsection{Reflective Practices in Mobile Learning Platform}

John Dewey (1933) introduced about the concept of "reflective thinking" in his book "How We Think" to represent "active, persistent, and careful consideration of any belief or supposed form of knowledge in the light of the grounds that support it and the further conclusion to which it tends" (Dewey, 1933, p.9). In his book, reflection involves the learner as the object of reflection.

In 1987, Donald Schon in his book of "The Reflective Practitioner: how professionals think in action" stated that a learner who practices reflective thinking is aware of own cognition, and the constant cognition enabled the learner to have a solution which is out of the box thinking. Meaning, the learner recognizes that every given problem or interpretation of a circumstance may have more than one solution if the learner practices and continues thinking. Schon (1987) created the first term of "reflection-in-action as a thought that a learner takes while involved in a circumstance, during which the learner become aware of what one is thinking, feeling and doing and the second term of reflection-on-action takes place sometime later, when the learners consider the events that took place, and recall what the learners were thinking, feeling and doing" (Hickson, 2011, p.831). Later, Thompson (2008) added another dimension to this practice called reflection-for-action, which is planning ahead and reflecting on what may happen, allowing for preparation and anticipation of a situation. Therefore, this study has employed the same process of the three phases (pre, during, and post-reflective) as what Schon (1987) and Thompson, (2008) mentioned in their studies. Substantively, this study used Gibbs' reflective cycle as a guide in designing the three reflective questions.

In this digital age, the learner needs to be more alert and aware of receiving any kind of information which is easily available in Mlearning platform. This is because the learner has control over his own learning and has immediate and quick access to any information without any filtration. Zimmerman (2008) argues that the M-learning platform has the potential to improve the learning experience, and at the same time require skills like goal setting, monitoring, controlling cognition, and motivation.

Aleja (2014) mentioned that technology enhances the learning environment as students have the freedom to navigate through the learning materials presented in text, audio, image and video formats, and thus, gives the students options which materials would suit the best. Reflective process "empower learners to become more independent in the approach to learning with, and about, computers in the future" (Phelps, Ellis, \& Hase, 2002, p.481). It is also found that the reflective process enables students to keep update with the rapid development of information technology where knowledge in using a particular piece of software is likely to become out-of-date over a short period of time (Phelps, Ellis, \& Hase, 2002).

Cacciamani, Cesareni, Martini, Ferrini, and Fujita (2012) found when online students were prompted with reflective practice questions which require the students to answer in a shared space during an online discussion, and those same students tend to demonstrate better epistemic knowledge than the students who were not prompted with reflective questions. The use of prompts is one approach to assist learners in problem solving but it is not necessarily the only available approach in the thinking processes that occur during the online discussion forums. Prompting learners to write for reflection can be a creative process contributing to change the writer's understanding of the topic (Bereiter \& Scardamalia, 2013). Prompts can refer to successful or unsuccessful learning experiences.

There are several reflections models in the literature (Gibb's reflective cycle, Atkins, \& Murphy, 1994; Bass, Fenwick, \& Sidebotham, 2017), hence this study chose Gibbs' reflective cycle as it helps the postgraduate students to think systematically about the different stages of their learning experience (Helyer, 2015). A study conducted by Ahmed (2019) employed Gibbs' reflective cycle to develop a reflective journal to help students at Qatar University to reflect on the instructional practices. This study was employed in a case study methodology, and the data were analysed using content analysis. The findings of the study revealed that students preferred teaching strategies such as gradual teaching, exemplification, discussion, comprehension checking, cooperative learning, and graphic organizers. In another study conducted by Mohamed Abdullah Turky (2016) aimed to investigate web 2.0 application usages in promoting reflective thinking skills for higher education students in the faculty of education. This study was used Gibbs' reflective cycle to foster reflective thinking skills. The findings of this study provided the students skills throughout the learning process. Another finding in terms of methodological was been rigorous evidence for learning and teaching innovation.

The researcher explored the use of reflective practices in identifying postgraduate students learning experience in the M-learning platform. Substantially, these students have been evaluated used task-centered activity to determine their learning experience in the M- 
learning platform. These students were introduced to the FutureLearn (MOOCs) platform which is one of the M-learning platforms and the reflective practices (pre-, during-, and post-reflective) take place throughout the M-learning process. To strengthen this study, the researcher used a Gibbs' Reflective cycle as a theoretical framework.

\subsection{Gibbs' Reflective Learning Cycle}

One of the prominent theory on reflective practice is derived from Gibbs' Reflective Learning Cycle (1988). Gibbs' reflective cycle is a popular model for reflection. Gibbs' reflective cycle encourages students to think systematically about the experiences that they had during the M-learning platform. There are six stages in this model such as description, feelings, evaluation, analysis, conclusion, and action plan. Using these six stages often allows the students to think about an experience in both good and bad. This makes the students aware of their own experience and makes sense of it in different situations in the future. Hence, students were engaged in reflective practices to reflect on their own meaningful learning experience in M-learning platform. These reflective practices enable the students to understand their learning and analysed their experiences. Therefore, the students able to transform their meaningful M-learning experiences to construct knowledge and understanding thus, perform in task-centered activity. The students develop the ability to integrate insights gained from the learning experience so that they can make precise choices and improve the learning through reflection (Rogers, 2001).

\subsection{The Role of Instructor as Facilitator}

The role of the instructor has transformed from being 'the source of knowledge' to a facilitator and role model in the process of acquiring knowledge and skills (Moodleroom, 2012). Therefore, "instructors need to provide learners with learning experiences that foster selfdirected learning, get learners actively involved in one's own learning process, and explicitly teach learners how to learn while guiding the learning process" (Francom, 2010, p.29). In addition, Rico and Ertmer (2015) examined the role of the instructor employing studentcentered approaches, specifically those that are problem-centered, result in outlining effective strategies that are valuable for facilitating discussions. Therefore, the instructor role in this study would facilitate regulations of cognitions in an interaction between the content (The FutureLearn course design) and the learner as a teaching presence, provide timely guidance, and support throughout the 10 weeks of Mlearning process. The interaction between instructor and learner are assumed to foster readiness towards self-directed learning in the Mlearning (Garrison, 2015).

\subsection{Research Objective}

The purpose of this study is to identify the postgraduate students M-learning experiences using reflective practice on task-centered activity based on FutureLearn (MOOCs) platform. The research objective of this study was to explore the postgraduate students learning experience in the M-learning platform using reflective practices on task-centered activity.

\subsection{METHODOLOGY}

This study is qualitative in nature and employed thematic analysis to identify the postgraduate students M-learning experience using reflective practices. This study used purposive sampling in choosing the 34 postgraduate students from Instructional Technology (IT) course in one of the public university in Malaysia. The rationale behind employed purposive sampling based on homogeneous sampling which focuses on one particular group that registers and enrolls for Instructional Technology (IT) course. Therefore, only 34 postgraduate students that registered and enrolled in Instructional Technology (IT) course for that particular semester. Besides that, this study used Gibbs' reflective cycle (1988) as a theoretical framework and to design reflective questions. Thus, this study used FutureLearn which is one of the platforms in MOOCs. FutureLearn is a UK-based MOOC initiative, which built on evidence-based online and mobile pedagogies (Sharples, 2013). FutureLearn was developed using a Responsive Web Design and optimised for any web-enabled mobile devices. This Responsive Web Design allowed the students to experiences the same website, regardless of the mobile device (FutureLearn blog, 2013). An online course which is 'Blended Learning: Getting Started' from FutureLearn is used for this M-learning. The whole process of this M-learning process lasted up to 10 weeks and the reflective practices took place before the students enrolled in the Mlearning process (pre-reflective), during the FutureLearn platform courses learning (during-reflective) and after completing the taskcentered activities (post-reflective). The overview of the M-learning process and reflective practices shown in Figure 1. 


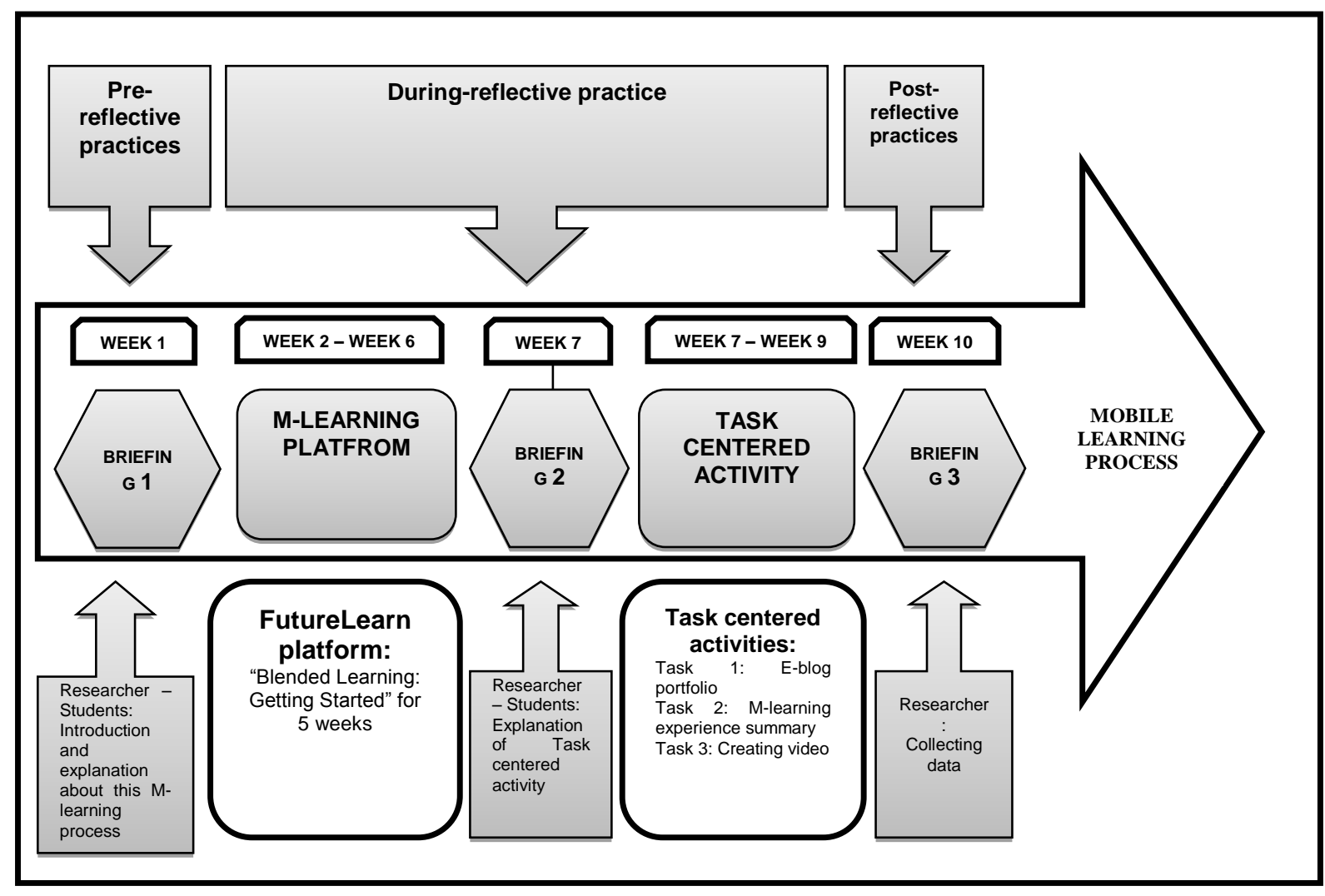

Figure 1 Overview of the M-Learning Process and Reflective Practices

\subsection{Postgraduate Students Background}

The total number of Postgraduate students from Instructional Technology (IT) course is 34 individual which comprise of 7 (20.5 \%) male and $27(79.5 \%)$ female. This study showed that the frequency of the students year of studies enrolled into IT course is from the first year with $26(76.6 \%)$ students and followed by a second and third year with $4(11.7 \%)$ students. The PG students who enrolled in IT course with different program of studies which is Instructional Technology and Educational Psychology of 9 (26.5\%) students, English Language Teaching with $7(20.6 \%)$ students, Curriculum \& Instruction with $6(17.6 \%)$ students and Islamic Education with 3 (8.8\%) students.

\subsection{Reflective Questions}

This study adopted Gibb's Reflective Cycle (1988) model to construct items based on these three reflection practices. There are six sections in this model and the first two sections (description and feelings) measures pre-reflective consisting of 5 items. The next two sections (evaluation and analysis) measured during reflective consists of 12 items. The last two sections (conclusion and action plan) measured the post-reflective phase and consist of 15 items. Two experts from a public university in IT in the education field reviewed and validated these reflective questions. Besides that, member checking was carried out by permitting the postgraduate students to review the reflective questions for validation purposes. The data from the reflective questions were analysed using the content analysis method. The content analysis involved a systematic coding process which entails coding, finding categories, and themes (Appendix).

\subsection{Data Collection}

Pre-reflective: In the first week (Week 1) the researcher of this study had a briefing section with the postgraduate students. The researcher briefly explained this M-learning process which comprises reflective practices, how M-learning works, and the three activities in taskcentered activity (creating an e-portfolio blog, writing M-learning experience, and creating 10 minutes video presentation based on Mlearning experiences). In the first week itself, the researcher provided the URL of Google Form where pre-reflective questions (5 Items) were uploaded online and requested the postgraduate students to access the URL using their mobile devices. The rationale behind uploading the reflective questions online is to ease the students learning process as well to foster online self-report learning experience. Later, the researcher explained the pre-reflective questions precisely and ensure that the postgraduate students understood. After the explanation, the researcher allowed the students to answer the pre-reflective questions and 15 minutes time duration were given in order to complete them. After the briefing section, the researcher of this study explained and demonstrated on the FutureLearn (MOOCs) platform features and the course content. The course that the postgraduate students need to attend is "Blended learning: Getting started" which runs 
for five weeks. After the brief explanation, the postgraduate students were allowed to register and enrolled in the FutureLearn (MOOCs) platform at their own pace.

During reflective: On the second week to the sixth week (Week 2 - week 6), the students enrolled in the FutureLearn platform for the course of 'Blended Learning: Getting Started' which ran for 5 weeks. During this stage, 12 reflective questions were posted online in the second week in Google Form. The researcher then emailed the link of Google Form to all the 34 participating students in this stage and the dateline to submit on the seventh week. During the second briefing, the researcher will explain about the task-centered activities while distributed the task to the students. The students used the five weeks session to reflect on their learning experience upon ones' learning on the reflective questions.

Post-reflective: On the seventh to ninth week (Week 7 - week 9), the students answered the task-centered activity which comprises three questions. These three questions were on creating an e-portfolio blog, writing M-learning experience, and creating a 10 minutes video presentation based on M-learning experiences. The three weeks duration during this task-centered activity allows the students to selfreflect and thus refined the task. In week eight, the postgraduate students were required to email their blog URLs to the researcher. Every students have their own individual blog URL to exhibit their work. The researcher recorded all the 34 postgraduate students blog URLs. The postgraduate students task-centered activity was evaluated based on the rubric. After gathering all these 34 postgraduate students blog URLs, the researcher requested the students to access the online post-reflective questions in Google Form. The researcher allocated the students 15 minutes to answer the post-reflective questions and had them submitted back to the Google Form. Upon completion, all the students were dismissed.

\subsection{RESULTS}

From analysis of the data, three distinct themes were identified. Aligning with a Self-Regulated Learning theory framework (Boekaerts, 1999) each identified theme is discussed thoroughly supported with the related literature.

\section{Pre-Reflective Practice On Mobile Learning Experiences}

After the briefing section by the instructor of this course, the pre-reflective questions were uploaded online to the postgraduate students. At the beginning stage, the majority of the students have mentioned that they were "unsure of M-learning". This shows that the students were not sure of their experience in the actual role of M-learning especially when the students were requested to use their own mobile devices in the FutureLearn platform. Besides that, some students reported being clueless about handling the FutureLearn platform as the students had no idea what to do next. This was because the students were unable to imagine what was supposed to be done next and how to handle this platform which was a new learning experience. However, the students with limited prior knowledge of M-learning were ready and enthusiastic to explore as it triggers the student interest to learn new knowledge in the new learning environment. Even though the students were ready to explore the FutureLearn platform yet the limited prior knowledge that the students have had restricted the students to develop the cognition load.

"I have no idea what is mobile learning and MOOC" (S8)

"I'm clueless what to do next and how to handle it as I never experience this before". (S6)

"I have heard about this FutureLearn platform but never explore by my own and this platform triggered my interest to learn new information in new learning environment". (S9)

"I have no idea about this learning platform yet I am ready to explore based on prior knowledge". (S34)

\section{During-Reflective Practice On Mobile Learning Experiences}

The postgraduate students the reflective practice was divided into M-learning experiences which encompassed positive and negative experiences. At this phase, the students oversaw the actual learning experience in this FutureLearn (MOOCs) platform. The students did not only monitor the action but also kept track of ones' progress towards their goals. Therefore, the students were able to develop the cognitive load by drawing their own goals and strategies to handle the learning platform efficiently. In addition, the students gained epistemic belief when the platform gave new learning experience on new technological tools. This experience has proven that learning new technology tools in FutureLearn (MOOCs) platform is beneficial, interesting, fun, flexible, simple course content, easy to access and it promotes collaborative learning. This indicates that these students enjoyed this platform that triggered their intrinsic interest to learn new knowledge which is beneficial for their future learning. Besides that, there were several students who mentioned that they were able to find a suitable time amidst their busy schedule to actively engage and precautioned to avoid disruption from the internet connection for peaceful learning. This showed that the students develop self-control on time management by familiarizing themselves with the FutureLearn (MOOCs) platform environmental structure. Furthermore, a few students reported that some course content in the FutureLearn (MOOCs) platform is difficult to be understood which demotivated them to learn further. Yet, the students reflective practice aided the students to be motivated. The students managed to overcome all the challenges and continued working on the assigned activities without giving up. Thus, the analysis proved that the students valued the task, which conditions the students motivation and effort, and consequently, lengthen their attention span.

"Yes, this platform is interesting, fun, flexible, simple course content, easy to access and collaborative learning". (S6)

"I think the FutureLearn is beneficial to me. I learn many technology tools to help my teaching. "I enjoy the tools introduced to me. I used different tools in different situations". (S29) 
"I'm thinking on organizing the right time to get involved in this is FutureLearn platform amidst of my busy schedules after my work time". (S15)

"I need to have my own strategy to handle this learning platform as I'm not technologically proficient and also managing the time wisely. "(S25)

"Some course content is difficult for as I'm losing my interest to further up the learning yet I never give up and keep motivating me to move on and also taking it as challenges for myself". (S6)

The postgraduate students gained negative experiences during the M-learning process in FutureLearn (MOOCs) platform. The majority of the students admitted that being technologically illiterate very often inhibits them from using online learning platforms such as the FutureLearn (MOOCs) videos using mobile devices. These students were not technologically fit thus, the need of instructor helped in easing the learning process which was crucial. A few students reported feeling insecure as the students did not know how to seek help when faced with a technical problem such as content compatibility, mobile screen size resolution adjustment, and incompatible devices, while using the mobile devices. Quite common, the anxiety and insecurity demotivated and lowered the interest of the students to get engaged in this FutureLearn (MOOCs) platform. Due to a lack of interest and motivation, the students did not really accept the epistemic belief of the platform while at the same time, the students refused to explore beyond the course content and constantly show negative responses to this M-learning process. In addition, the students kept saying that lack of time to attend this FutureLearn (MOOCs) platform was another strong reason to be explored further.

"Can't catch up with the technology skills needed". (S23)

"I'm feeling insecure when dealing with the technology as I am not good in it and I need instructor guidance all the time".

(S12)

"I have not enough time to get engage actively in this platform as I don't have motivation to learn this platform”. (S8)

\section{Post-Reflective Practice At Mobile Learning Experiences}

Positive experiences encapsulated the postgraduate students optimistic about completing task-centered activity based on their actual learning experience in FutureLearn (MOOCs) platform. The outcome of this learning experience is that all the students succeeded in completing these task-centered activities. The students were enthusiastic to learn new experience and knowledge resulting from the taskcentered activities. The majority of the students mentioned that epistemic belief enabled the students to comprehend the benefit of this FutureLearn (MOOCs) platform as it helped to increase their performance level in the task-centered activities. The students strong motivation also helped to increase their performance level as the students set different strategies to approach the difficult course content of the FutureLearn (MOOCs) platform. It is also found that students evaluated the strategies and outcomes matching the goals settings. Meanwhile, the students who were not confident of ones' work were reported to do an additional search for other sources from the internet to improve the students work. This additional effort denoted that students were trying to be creative. Others meanwhile, will refer to the instructors for confirmation.

"I am glad to learned new experience and knowledge". (S29)

"I have learned a lot in joining FutureLearn. I have completed all the task in FutureLearn (MOOC) and also have completing my task centered activity”. (S16)

"It was a great experience exploring the MOOCs. Yes, I am able to complete". (S23)

"I completed this activity and this platform is really beneficial". (S13)

"I evaluate my own strategies to check whether its work well and I know where to find additional source to support my work". (S31)

Negative experiences encapsulated the postgraduate students undesirable experiences on completing the task-centered activity. Therefore, students reported that due to the lack of technology proficiency and time constraint were the main reasons behind the students negative Mlearning experience. Therefore, the students tend to do the task-centered activity at the surface level and did not intend to try any creativity in the work. The students seem to complete the task forcingly and did not indulge in the students own interest. Thus, there is no quality in the completed work.

"I as a working mother have to struggle in term of finding perfect time to do these activities". (S25)

"Was having quite a difficult time in the process of task centered activity as I'm not expert in IT with limited time. But anyway, i did complete!" (S13)

The above findings reported that reflective practice has impact the students learning on FutureLearn (MOOCs) platform. The students at this beginning level were unsure of M-learning but gradually had significant improvement in ones' involvement and cognitive skills. These students with positive M-learning experiences would enable them to draw the students own goals and strategies to complete the taskcentered activity successfully. The platform was reported to be very beneficial. On the other hand, the students with a negative experience with a moderate level of reflective process reported that their technology proficiency decreases interest and self-confidence.

\subsection{DISCUSSION}

The first main finding is, majority of the students were unsure of M-learning and FutureLearn (MOOCs) platform process. This is because of the students were unaware or not ready for this M-learning process. These students also reported that lack of M-learning experience based on prior learning experience is a reason for unfamiliarity about the FutureLearn (MOOCs) platform. The students also became clueless in handling this FutureLearn (MOOCs) platform as the students had no idea what to do next. This is because the students were unable to imagine what was supposed to be done next and how to handle this platform as the students were not exposed to this kind of 
learning before. Therefore, this illustrates that limited prior knowledge will restrict the students to develop deeper thinking. The reflective practices proposed that findings from Ionas, Cernusca, and Collier (2012) at USA Midwestern College were aligned to the fact that prior knowledge enhanced the effectiveness of learning.

The second main finding is students with positive M-learning experiences able to perform well in the task-centered activity. The students reflective practices worked when they constantly requested to think about their M-learning process based on their actual learning experience in the M-learning platform. Subsequently, the students cognition work in parallel when their match prior experience with the new learning experience, and this lead to a meaningful learning experience. As they perceived new learning experience, the students will think continuously to update their own mental models and this innate curiosity on how this M-learning platform works and how their can perform well while evaluating their progress towards goal settings, and strategies. Thus, the reflective practices enable the students evolved to plan, monitor and evaluate their performance in the M-learning platform and task-centered activity. Moreover, the students epistemic belief and intrinsic interest enabled the students to actively engage and to repeatedly think over the activities, finally allowing the students to figure out solutions for any challenges and difficulties that were faced during this learning process. Thus, the analysis value the task, this conditions the motivation and effort, and therefore, the attention span during the performance increases. These findings are in line with Mair (2012) where the use of technologies would facilitate and support deep thinking among the learners to create meaningful learning experiences.

The other vital finding is that the postgraduate students with negative M-learning experience were reportedly having a low level of thinking ability. It is found that it is quite difficult to plan, monitor, and evaluate the students own cognition and performance in the Mlearning platform and task-centered activity as they are not technologically literate. Students felt insecure as the students did not know how to seek help when faced with the technical problem while using mobile devices. Quite common, anxiety and insecurity demotivate and lowers the interest of the students to get engaged in any M-learning platform. Due to a lack of interest and motivation, the students did not really accept the epistemic belief of the platform while at the same time, the students refuse to explore beyond the course content and constantly show negative responses to this learning process. These findings are consistent with some findings from Azevedo \& Cromley (2004) which states that not all students have the ability to regulate cognition skills. The students reported basic technology knowledge is inadequate to aid in doing the online courses and thus, this develops insecurity and frustration which prohibits the students to direct ones' own learning. At this point, these students reported that the role of the instructor as a facilitator eases the M-learning process. The findings of this study support the result of research conducted by Rico and Ertmer (2015) which discussed the role of the instructor during the student-centered approaches. Therefore, this students reflection is low as the students never attempted to think over, overthink, or take initiative for finding the solution when faced with rigid circumstances in M-learning. These students either ignored the learning section or immediately seek help from the instructor when faced with challenging circumstances.

\subsection{IMPLICATION}

Learning experience is individualized as every student preferably may have positive or negative experiences based on their prior knowledge and own understanding. In this study, students with negative M-learning experience possessed a low level of reflecting ability. Thus, more focus should exert on the students with negative M-learning experience as they can impose on their performance level in the mobile-based task-centered activity. Therefore, reflective practices and the M-learning process has effects on students meaningful learning experiences (Figure 2).

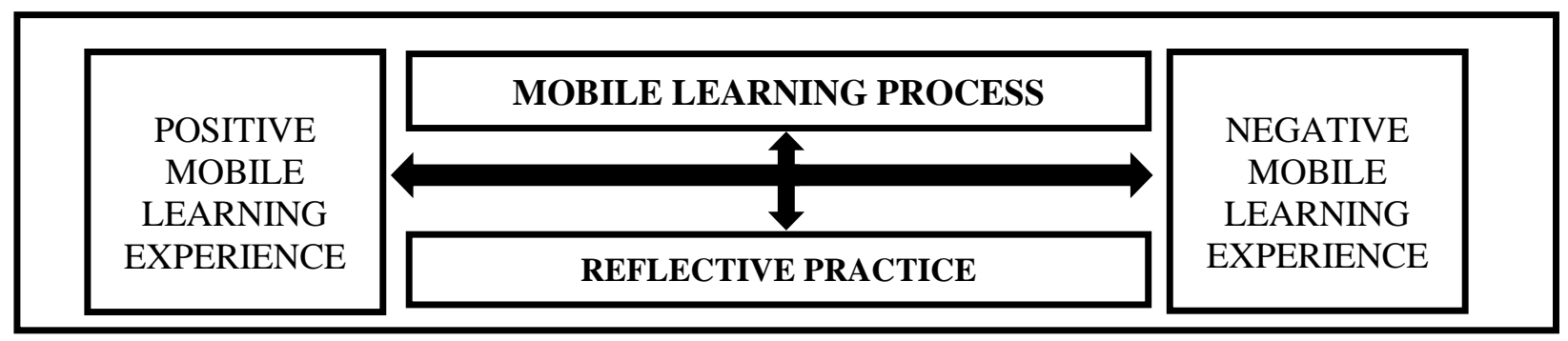

Figure 2 Effects on Reflective practice in Mobile Learning Experience through Task-Centered Activity

\subsection{CONCLUSION}

The present study sought to explore the postgraduate students voice on their learning experiences, thoughts and feelings in the M-learning platform, and task-centered activity. This study has found that postgraduate students reflective practices had a significant impact on increasing meaningful learning experience engaging the M-learning platform among students with positive M-learning experience. This means that students who have positive M-learning experience also have a high level of thinking skills meanwhile students with negative M-learning experience have a low level of thinking skills. Other than that, students self-directed learning is a construct that can be improved, it is suggested that instructors should take into consideration the source of self-directed learning and thus try to develop the students self-directed learning. Moreover, the outcomes from this study may help instructors to focus on interventions that help to develop the cognitive skills of the students which accommodate students strengths and ability levels. This M-learning experience enables the students to construct their own understanding through experiencing the actual learning experience in the M-learning platform and reflecting on those learning experiences. Therefore, reflective practices are essential tools where it allows students to think out of the box 
when faced with difficult situations. In the same light, the students will also develop critical thinking which directs to the right decision making and self-directed learning skills.

\section{References}

Aleje, O.P. (2014). Effects of Metacognitive Awareness on Learning in Technology Enhanced Learning Environments. Multidisciplinary Journal of Research Development, 22(1), 145-155.

Azevedo, R. \& Cromley, J. G. (2004). Does Training on Self-Regulated Learning Facilitate Students Learning with Hypermedia? Journal of Educational Psychology, 96(3), 523-535.

Al-Hunaiyyan, A., Alhajri, R. A., \& Al-Sharhan, S. (2018). Perceptions and challenges of mobile learning in Kuwait. Journal of King Saud University - Computer and Information Sciences, 30(2), 279-289. https://doi.org/10.1016/j.jksuci.2016.12.001

Alsadoon, E. (2018). The Impact of Social Presence on Learners' Satisfaction in Mobile Learning. Turkish Online Journal of Educational Technology - TOJET, 17(1), 226-233.

Anderson, G.L., \& Herr, K. (1999). The new paradigm wars: Is there room for rigorous practitioner knowledge in schools and universities? Educational Researcher, $28(5), 12-21$.

Atkins, S., \& Murphy, K. (1994). Reflective practice. Nursing Standard, 8(39), 49-56.

Bass, J., Fenwick, J., \& Sidebotham, M. (2017). Development of a Model of Holistic Reflection to Facilitate Transformative Learning in Student Midwives. Women and Birth, 30(3), 227-235.

Bereiter, C., \& Scardamalia, M. (2013). The Psychology of Written Composition. Routledge, Abingdon.

Boud, D. \& Walker, D. (1991). Experience and Learning: Reflection at Work. Geelong, Australia: Deakin University Press.

Cacciamani, S., Cesareni, D., Martini, F, Ferrini, T., \& Fujita, N. (2012). Influence of Participation, Facilitator Styles, and Metacognitive Reflection on Knowledge Building in Online University courses. Computers and Education, 58(3), 874-884. doi: 10.1016/j.compedu.2011.10.019

Dewey, J. (1933). How we think: a restatement of the relation of reflective thinking to the educative process. Chicago IL: Henry Regnery Co.

FutureLearn blog. (2013). Being responsive. Blogpost. Retrieved from https://about.futurelearn.com/blog/being-responsive/

Grant, M. M., \& Barbour, M. K. (2013). Mobile teaching and learning in the classroom and online: Case studies in k-12. In Z. L. Berge \& L. Y. Muilenburg (Eds.) (Ed.), Handbook of mobile learning (pp. 285-292). New York: Routledge. Garrison, D. R. (2015). Thinking collaboratively: Learning in a community of inquiry. Florence, KY: Taylor and Francis.

Gibbs, G. (1988). Learning by Doing: A Guide to Teaching and Learning Methods. Oxford: Oxford Further Education Unit.

Helyer, R. (2015). Learning through Reflection: The Critical Role of Reflection in Work-Based Learning (WBL). Journal of Work-Applied Management, 7(1), 15-27.

Harvey, M., Walkerden, G., Semple, A.-L., Mclachlan, K., \& Lloyd, K. (2019). What we can learn from the iReflect project: Developing a mobile app for reflection in work-integrated learning. International Journal of Work-Integrated Learning, 20(1), 55-69.

Hickson, H. (2011). Critical reflection: Reflecting on learning to be reflective. Reflective Practice, 12(6), 829-839. https://doi.org/10.1080/14623943.2011.616687 Ionas, I.G., Cernusca, D., \& Collier, H.L. (2012). Prior Knowledge Influence on Self-explanation Effectiveness when Solving Problems: An Exploratory study in Science Learning. International Journal of Teaching and Learning in Higher Education, 24(3), 349-358.

Johnson, L., Adams Becker, S., Cummins, M., Freeman, A., Ifenthaler, D., \& Vardaxis, N. (2013). Technology outlook for Australian tertiary education 2013-2018. An NMC Horizon project regional analysis. Austin, Texas: The New Media Consortium.

Law, E. L. C., \& Sun, X. (2012). Evaluating user experience of adaptive digital educational games with Activity Theory. International Journal of Human Computer Studies, 70(7), 478-497. https://doi.org/10.1016/j.ijhcs.2012.01.007

Marinagi, C., Skourlas, C., \& Belsis, P. (2013). Employing ubiquitous computing devices and technologies in the higher education classroom of the future. ProcediaSocial and Behavioral Sciences, 73, 487-494. https://doi.org/https://doi.org/10.1016/j.sbspro.2013.02.081

Mair, C. (2012). Using Technology for Enhancing Reflective Writing, Metacognition and Learning. J Furth High Education, $36(6), 147-167$.

Moodlerooms. (2012). About Moodle. Retrieved June 22, 2012 from http://www.moodlerooms.com/resources/moodle-resources/.

Poore, M. (2016). Using social media in the classroom: A best practice guide. London, England: SAGE Publications Ltd.

Phelps, R., Ellis, A., \& Hase, S. (2002). The Role of Metacognitive and Reflective Learning Processes in Developing Capable Computer Users. Proceedings of the 18th Annual Conference of the Australasian Society for Computers in Learning in Tertiary Education (ASCILITE), 9-12 December 2001, 481-490. Melbourne.

Rico, R., \& Ertmer, P. A. (2015). Examining the Role of the Instructor in Problem-centered Instruction. Tech Trends, 59(4), 96-103.

Sánchez-Prieto, J. C., Olmos-Migueláñez, S., \& García-Peñalvo, F. J. (2016). Informal tools in formal contexts: Development of a model to assess the acceptance of mobile technologies among teachers. Computers in Human Behavior, 55, 519-528.

Schön, D. (1987). A review of Educating the Reflective Practitioner. San Francisco: Jossey-Bass.

Sharples, M. (2013). FutureLearn and Pedagogy. Internal Presentation Circulated during Learning Fair at The Open University.

Sonmez, A., Goçmez, L., Uygun, D., \& Ataizi, M. (2018). A Review of Current Studies of Mobile Learning. Journal of Educational Technology \& Online Learning, $1(1), 13-27$

Thompson, N. (2008). The Critically Reflective Practitioner. Basingstoke: Palgrave Macmillan.

Zimmerman, B.J. (2002). Becoming a Self-Regulated Learner: An overview. Theory into Practice, 41(2), 1-37. https://doi.org/10.1207/s15430421tip4102_2

Zimmerman, B.J. (2008). Investigating Self-Regulation and Motivation: Historical background, Methodological Developments, and Future Prospects. American Educational Research Journal, 45(1), 166-183. 